\title{
Thapsigargin induces apoptosis of prostate cancer through cofilin-1 and paxillin
}

\author{
FENGYU HUANG $^{1,2}$, PEITAO WANG $^{3}$ and XINSHENG WANG ${ }^{3}$ \\ ${ }^{1}$ Department of Clinical Medicine, Medical College of Qingdao University, Qingdao, Shandong 266021; \\ ${ }^{2}$ Department of Urology, Yantai Municipal Laiyang Central Hospital, Laiyang, Shandong 265200; \\ ${ }^{3}$ Department of Urology, The Affiliated Hospital of Qingdao University, Qingdao, Shandong 266011, P.R. China
}

Received May 15, 2016; Accepted April 13, 2018

DOI: $10.3892 / \mathrm{ol} .2018 .8833$

\begin{abstract}
It is widely considered that endoplasmic reticulum stress may rapidly induce apoptosis. The aim of the present study was to investigate the effect of thapsigargin on the induction of apoptosis in prostate cancer cells, and to explore its possible mechanism. A Cell Counting Kit- 8 was selected to determine the effect of thapsigargin $(0,1,10$ and $100 \mathrm{nM})$ on the proliferation of PC3 cells. Cell proliferation of the prostate cancer cells was effectively inhibited by treatment with thapsigargin, and thapsigargin significantly increased the rate of apoptosis and caspase-3/9 activities in prostate cancer cells. The protein expression of phosphorylated (p)-RAC- $\alpha$ serine threonine-protein kinase, $p$-mechanistic target of rapamycin, F-actin and paxillin were significantly decreased, and cofilin-1 protein expression was significantly increased by treatment with thapsigargin in prostate cancer cells. Overall, the data of the present study revealed that thapsigargin induced apoptosis in prostate cancer cells through cofilin-1 and paxillin.
\end{abstract}

\section{Introduction}

Prostate cancer is one of the most common types of cancer in men and the mortality rate was $9.37 / 100,000$ in 2012, which has increased yearly in China (1). An increasing amount of evidence has indicated that age, ethnicity and family history of prostate cancer are factors associated with morbidity of prostate cancer (2). The occurrence and development of prostate cancer may be the result of the interaction between genetic predisposition and environmental factors, while genetic variation determines the susceptibility of individuals to suffer from prostate cancer (3). At present, the involvement of whole-genome analysis of different

Correspondence to: Mr. Xinsheng Wang, Department of Urology, The Affiliated Hospital of Qingdao University, 16 Jiangsu Road, Qingdao, Shandong 266011, P.R. China

E-mail: spuwqvvi56@126.com

Key words: thapsigargin, prostate cancer, cofilin-1, paxillin ethnic groups worldwide has revealed that there are $>30$ susceptible sites on the genome associated with the risks of prostate cancer occurrence (4). The study of a genetic predisposition to prostate cancer, has demonstrated notable results $(4,5)$.

The apoptosis signaling pathway is stimulated by exogenous and endogenous stresses (6). These specific stresses are: Unfolded protein accumulation in the endoplasmic reticulum; disordered ingestion and release of endoplasmic reticulum calcium; and incorrect processing of specific proteins, either accompanied or unaccompanied, in the endoplasmic reticulum (6). Sustained endoplasmic reticulum stress results in apoptosis (7). Caspase-3 is a member of the caspase protein family, and is located in the endoplasmic reticulum (8). The specificity of caspase- 3 may be activated by endoplasmic reticulum stress.

Cofilin is a type of actin binding protein in eukaryons with a low molecular weight (9). The cofilin-1 gene is positioned at chromosome 11q13 and is expressed in non-muscular tissues (9). F-actin regulates the reconstruction of the actin framework and moves cells forward by reconstructing the schistose pseudopodia and lamellar structures of the front histiocyte (10). Highly activated cofilin-1 has been demonstrated in glioma, Lymphocytoma cutis, colon cancer, hepatoma carcinoma, renal carcinoma, esophageal squamous cancer and prostate cancer cells (11).

Paxillin is a phosphoric acid protein, with a molecular mass of $68 \times 10^{3}$, and its main role is in the process of focal adhesion (12). It functions to combine vinculin and actin (12). The human paxillin gene is positioned at chromosome $12 \mathrm{q} 24$, and there are 11 expressed regions (13). The paxillin molecule contains multiple structural domains and a combination of a series of signal proteins and structural proteins to mediate cell signaling transduction (13). It serves an important role in cell adhesion and transport processes, and has a close association with localized cancer cell movement (13).

It is widely hypothesized that thapsigargin (Fig. 1) induces endoplasmic reticulum stress, and may induce multiple cells to undergo endoplasmic reticulum stress and apoptosis (14). It has been demonstrated that thapsigargin may inhibit A549 cell growth, the source of which type II alveolar epithelial cells, and induce apoptosis (14). Concurrently, thapsigargin 
may induce leukemic K562 cells to undergo apoptosis in response to endoplasmic reticulum stress (15). The action of thapsigargin is to suppress activity of the endoplasmic reticulum membrane $\mathrm{Ca}^{2+}$-adenosine 5'-triphosphate enzyme, induce the increase in concentration of intracytoplasmic $\mathrm{Ca}^{2}$ and reduce the level of stored calcium in the endoplasmic reticulum, so as to cause endoplasmic reticulum stress and induce apoptosis (16). The present study explored whether thapsigargin induced apoptosis in prostate cancer cells, and explored its possible mechanism.

\section{Materials and methods}

Cell culture. The human prostate cancer PC 3 cell line was purchased from the Shanghai Cell Bank of The Chinese Academy of Sciences (Shanghai, China) and maintained in RPMI-1640 media (Hyclone; GE Healthcare Life Sciences, Logan, UT, USA) containing $10 \%$ fetal bovine serum (Hyclone; GE Healthcare Life Sciences) and $100 \mu \mathrm{g} / \mathrm{ml}$ penicillin-streptomycin (Invitrogen; Thermo Fisher Scientific, Inc., Waltham, MA, USA) at $37^{\circ} \mathrm{C}$ and $5 \% \mathrm{CO}_{2}$.

Cell proliferation assay. The Cell Counting Kit-8 (CCK-8, Beyotime Institute of Biotechnology, Haimen, China) was selected to determine the effect of thapsigargin $(0,1,10$ and $100 \mathrm{nM}$ ) on PC3 cell proliferation. The PC3 cells were seeded in 96-well plates at a density of $1 \times 10^{4}$ cells/well and incubated with thapsigargin $(0,1,10$ and $100 \mathrm{nM})$ for 12,24 and $48 \mathrm{~h}$ at $37^{\circ} \mathrm{C}$. Then, $10 \mu \mathrm{l} \mathrm{CCK}-8$ reagent was added and incubated for $4 \mathrm{~h}$ at $37^{\circ} \mathrm{C}$. Cell proliferation was detected at $450 \mathrm{~nm}$ using a microplate reader (Bio-Rad Laboratories, Inc., Hercules, CA, USA).

Flow cytometric analysis for cell apoptosis. The PC3 cells were seeded in 6 -well plates at a density of $1 \times 10^{6}$ cells/well and incubated with thapsigargin $(0,1,10$ and $100 \mathrm{nM})$ for $24 \mathrm{~h}$ at $37^{\circ} \mathrm{C}$. The PC 3 cells were washed with cold PBS twice, and re-suspended with $500 \mu 1$ binding buffer (BD Biosciences, Franklin Lakes, NJ, USA). Then, $5 \mu \mathrm{l}$ Annexin V-fluorescein isothiocyanate (BD Biosciences) was added to the cells and incubated for $30 \mathrm{~min}$ at $4^{\circ} \mathrm{C}$ in the dark. FACSCalibur flow cytometry (BD Biosciences) was performed following the addition of $10 \mu \mathrm{l}$ propidium iodide for $15 \mathrm{~min}$ in the dark at room temperature and Flowjo software (version 7.6.1; (FlowJo LLC, Ashland, OR, USA) was used to analyze apoptosis rate.

Caspase- 3 and caspase- 9 activity analysis. The PC 3 cells were seeded in 96 -well plates at $1 \times 10^{4}$ cells/well and incubated with thapsigargin $(0,1,10$ and $100 \mathrm{nM})$ for $24 \mathrm{~h}$ at $37^{\circ} \mathrm{C}$. A total of $100 \mu \mathrm{l}$ caspase- 3 or caspase- 9 reagent (C1136 or C1158, Beyotime Institute of Biotechnology) was added and incubated at room temperature for an additional $2 \mathrm{~h}$. Caspase-3 and caspase- 9 activity was detected at $490 \mathrm{~nm}$ using a microplate reader (Bio-Rad Laboratories, Inc.).

Western blot analysis. The PC3 cells were seeded in 6-well plates at $1 \times 10^{6}$ cells/well and incubated with thapsigargin $(0,1,10$ and $100 \mathrm{nM})$ for $24 \mathrm{~h}$ at $37^{\circ} \mathrm{C}$. Then, the PC 3 cells were washed with cold PBS twice and prepared using a ProteoJET

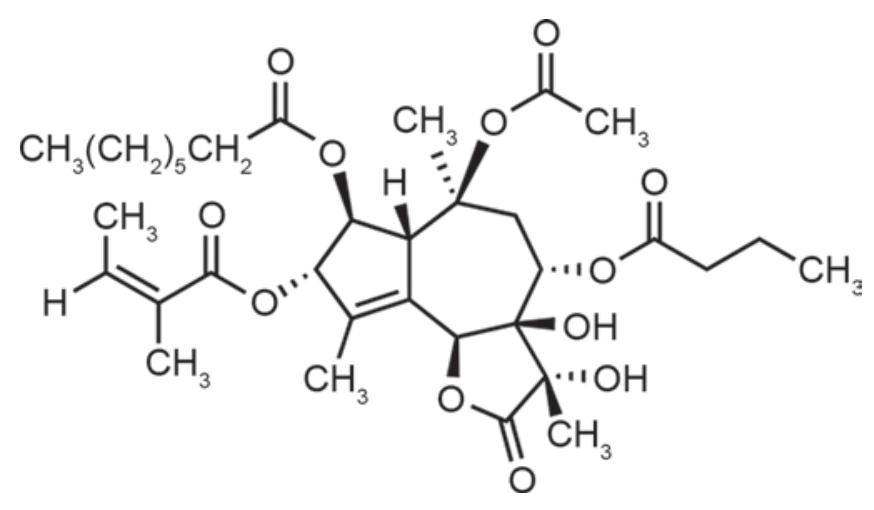

Figure 1. Chemical structure of thapsigargin.

cytoplasmic protein extraction kit (Fermentas; Thermo Fisher Scientific, Inc.). Protein concentrations were measured using a BCA Protein Assay kit (Thermo Fisher Scientific Inc.). Protein $(30 \mu \mathrm{g})$ was separated by 10-12\% SDS-PAGE and transferred electrophoretically using a PVDF membrane by standard procedures. The PVDF membrane was blocked for $2 \mathrm{~h}$ with $5 \%$ non-fat milk in TBST (TBS $+0.1 \%$ Tween-20) at $37^{\circ} \mathrm{C}$ and probed overnight using the following primary antibodies: Anti-RAC- $\alpha$ serine threonine-protein kinase (Akt, sc-135829; 1:1,000; Santa Cruz Biotechnology, Inc., Dallas, TX, USA); anti-phosphorylated (p)-Akt (sc-7985-R; 1:500; Santa Cruz Biotechnology, Inc.); anti-p-mechanistic target of rapamycin (p-mTOR; sc-101738; 1:500; Santa Cruz Biotechnology, Inc.); anti-F-actin (ab205; 1:1,000; Santa Cruz Biotechnology, Inc.); anti-cofilin-1 (sc-376476; 1:1,000; Santa Cruz Biotechnology, Inc.); anti-paxillin (sc-390738; 1:1,000; Santa Cruz Biotechnology, Inc.); and anti- $\beta$-actin (sc-1616; 1:2,000; Santa Cruz Biotechnology, Inc.), in PBST at $4^{\circ} \mathrm{C}$. Then, the membrane was incubated with horseradish peroxidase-conjugated goat anti-rabbit secondary antibody (1:2,000 dilution; sc-2004 or sc-2005, Santa Cruz Biotechnology, Inc.) for $2 \mathrm{~h}$ at room temperature and detected by Super Signal enhanced chemiluminescence development (ECL) reagent (Pierce; Thermo Fisher Scientific, Inc.) and analyzed using sodium Image Lab software (version 3.0; Bio-Rad Laboratories, Inc.).

Statistical analysis. Data are expressed as mean \pm standard deviation and were analyzed using the SPSS version 17.0 software (SPSS, Inc., Chicago, IL, USA). A one-way analysis of variance and Tukey's post-hoc test was used to compare data between groups. $\mathrm{P}<0.05$ was considered to indicate a statistically significant difference.

\section{Results}

Thapsigargin inhibits cell proliferation in prostate cancer cells. The present study demonstrated that thapsigargin may suppress cell proliferation of prostate cancer PC 3 cells in a dose- and time-dependent manner (Fig. 2). Treatment with 10 and $100 \mathrm{nM}$ thapsigargin at 24 or $48 \mathrm{~h}$ or 1,10 and $100 \mathrm{nM}$ thapsigargin at $12 \mathrm{~h}$ significantly suppressed cell proliferation of PC3 cells, compared with $0 \mathrm{nM}$ of thapsigargin (Fig. 2). 


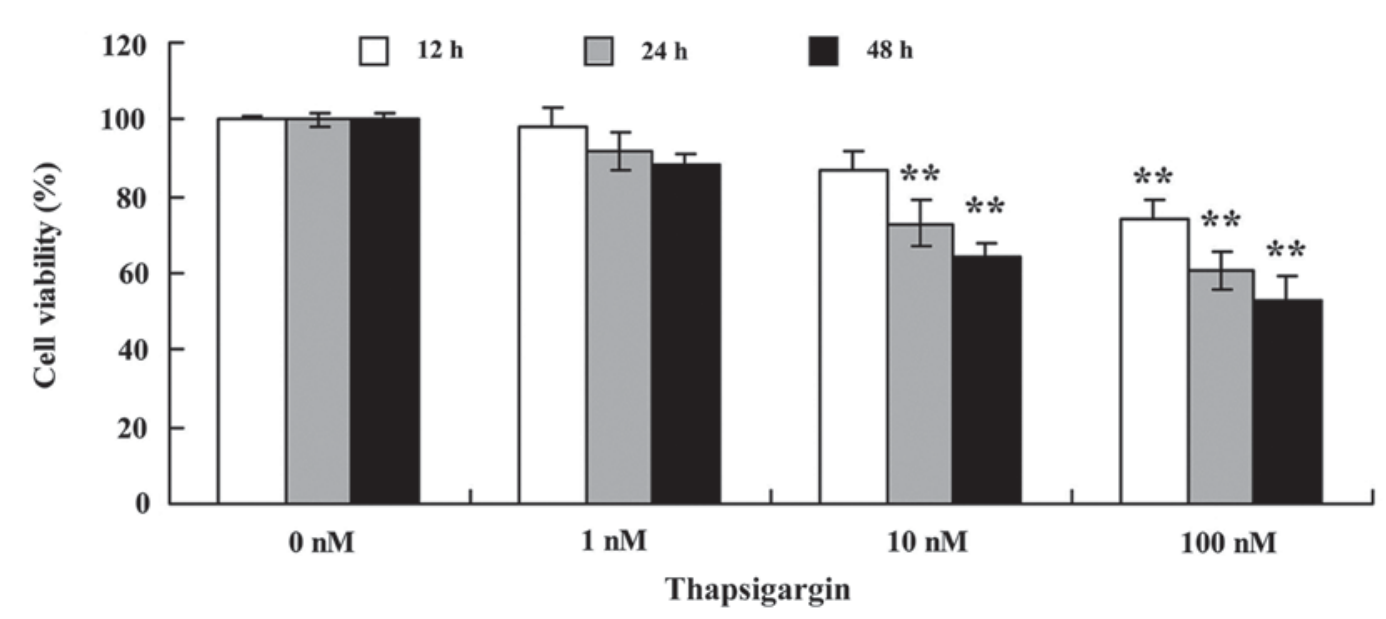

Figure 2. Thapsigargin inhibits cell proliferation in prostate cancer cells. ${ }^{* *} \mathrm{P}<0.01$ compared with $0 \mathrm{nM}$ thapsigargin group.

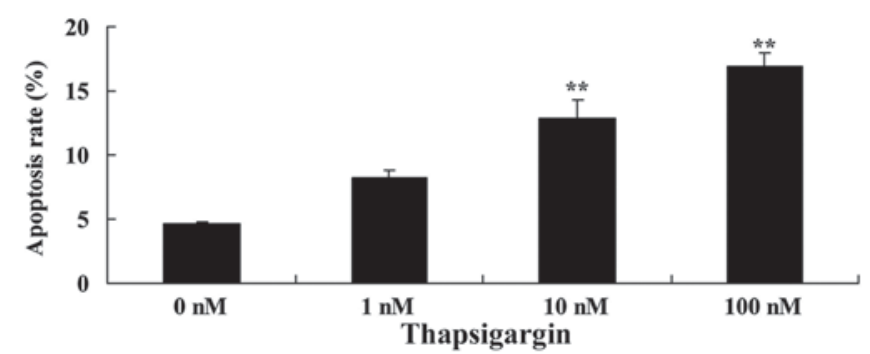

Figure 3. Thapsigargin induces apoptosis rate of prostate cancer cells. ${ }^{* *} \mathrm{P}<0.01$ compared with $0 \mathrm{nM}$ thapsigargin group.

Thapsigargin increases the apoptosis rate in prostate cancer cells. Consistent with the aforementioned data, 10 and $100 \mathrm{nM}$ thapsigargin significantly increased the apoptosis rate of prostate cancer PC 3 cells in a dose-dependent manner (Fig. 3). These data suggest that thapsigargin may suppress cell proliferation and increase the apoptosis rate of PC3 cells as a potential treatment for prostate cancer.

Thapsigargin induces caspase-3/9 activities in prostate cancer cells. To explore the anticancer effects of thapsigargin on cell apoptosis, caspase-3/9 activities in PC3 cells were then examined. Treatment with 10 and $100 \mathrm{nM}$ thapsigargin significantly increased caspase- 9 activities, and treatment with $100 \mathrm{nM}$ thapsigargin significantly increased caspase-3 activities in PC3 cells compared with the $0 \mu \mathrm{M}$ thapsigargin group (Fig. 4).

Thapsigargin inhibits Akt in prostate cancer cells. To confirm the potential mechanism of thapsigargin action, p-Akt and Akt protein expression levels were investigated by western blot analysis. As demonstrated in Fig. 5A and B, p-Akt protein expression was significantly decreased in PC3 cells by treatment with 10 and $100 \mathrm{nM}$ thapsigargin compared with the $0 \mathrm{nM}$ treatment group.

Thapsigargin inhibits mTOR expression in prostate cancer cells. Next, the p-mTOR expression level in prostate cancer cells was examined by treatment with thapsigargin in PC3 cells. Treatment with 10 and $100 \mathrm{nM}$ thapsigargin significantly

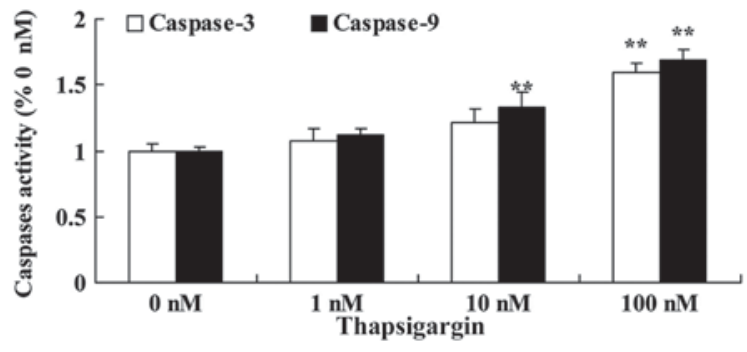

Figure 4. Thapsigargin induces caspase-3/and 9 activities of prostate cancer cells. ${ }^{* *} \mathrm{P}<0.01$ compared with $0 \mathrm{nM}$ thapsigargin group.

decreased p-mTOR protein expression in PC3 cells compared with the $0 \mu \mathrm{M}$ thapsigargin group (Fig. 5C).

Thapsigargin inhibits F-actin expression in prostate cancer cells. To determine the functional significance of F-actin in the regulation of the effect of thapsigargin on prostate cancer cells, F-actin protein expression was analyzed using western blot analysis. The western blot analysis data from the present study indicated that $\mathrm{F}$-actin protein expression was significantly decreased by treatment with $100 \mathrm{nM}$ thapsigargin in PC 3 cells compared with the $0 \mu \mathrm{M}$ thapsigargin group (Fig. 6A and B).

Thapsigargin induces cofilin-1 expression in prostate cancer cells. Furthermore, the effect of thapsigargin on cofilin-1 expression in prostate cancer cells was determined using western blot analysis. As indicated in Fig. 6A and C, treatment with $100 \mathrm{nM}$ thapsigargin significantly increased cofilin-1 protein expression in prostate cancer PC 3 cells compared with the $0 \mu \mathrm{M}$ thapsigargin group (Fig. $6 \mathrm{~A}$ and $\mathrm{C}$ ).

Thapsigargin inhibits paxillin expression in prostate cancer cells. To additionally confirm the inhibitory effect of thapsigargin on paxillin expression in prostate cancer cells, the protein expression of paxillin was measured using western blot analysis. Treatment with 10 and $100 \mathrm{nM}$ thapsigargin significantly decreased paxillin protein expression in prostate cancer PC 3 cells compared with the $0 \mu \mathrm{M}$ thapsigargin group (Fig. 6D). 

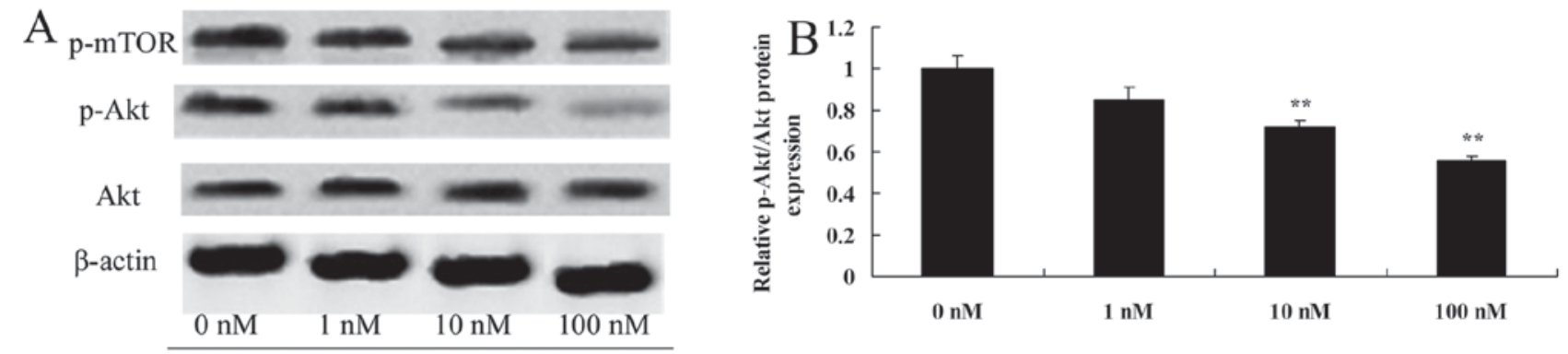

Thapsigargin

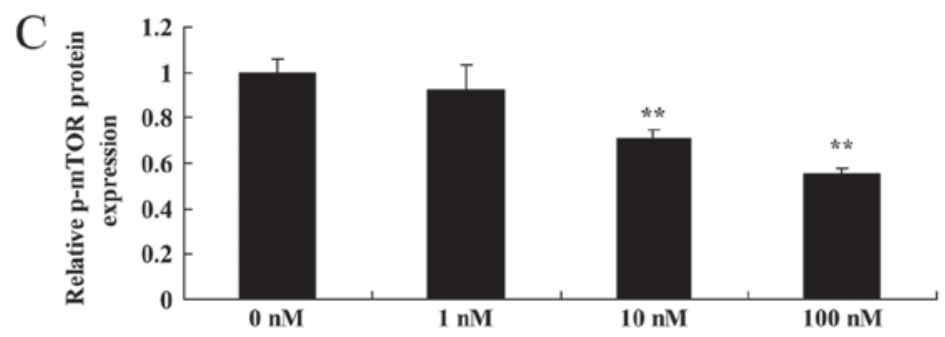

Figure 5. Thapsigargin inhibits PI3K/Akt of prostate cancer cells. Thapsigargin inhibits p-Akt/Akt protein expression by (A) western blot assays and (B) densitometric analysis of p-Akt/Akt protein expression of prostate cancer cells. (C) Thapsigargin inhibits p-mTOR protein expression. ${ }^{* *} \mathrm{P}<0.01$ compared with $0 \mathrm{nM}$ thapsigargin group.
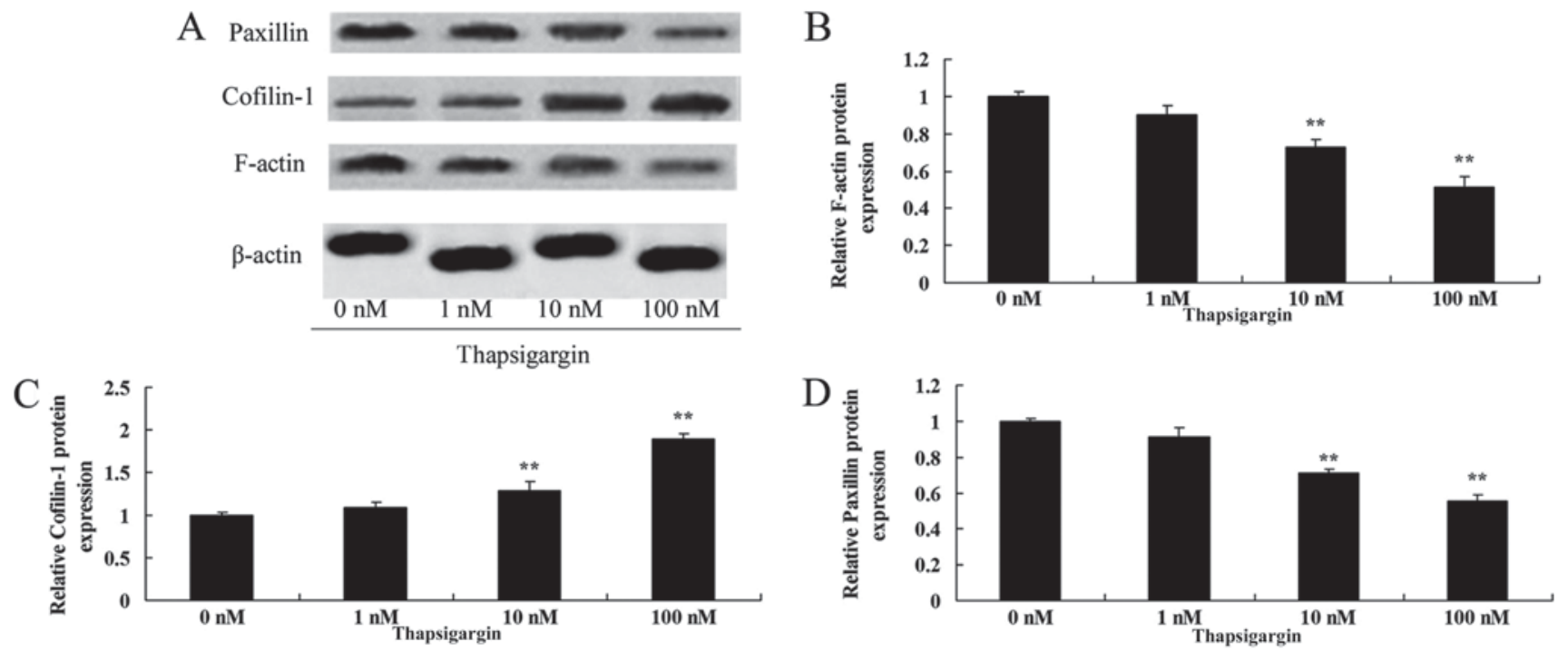

Figure 6. Thapsigargin inhibits F-actin, cofilin-1 and paxillin expression in prostate cancer cells. (A) Western blot analysis of the protein expression levels of F-actin, cofilin-1 and paxillin. (B) Densitometric analysis of F-actin expression. (C) Densitometric analysis of cofilin-1 expression. (D) Densitometric analysis of paxillin expression. ${ }^{* * *} \mathrm{P}<0.01$ compared with $0 \mathrm{nM}$ thapsigargin group.

\section{Discussion}

Prostate cancer is one of the most common types of malignant tumors. Its mortality rate ranks sixth globally (17). There are $\sim 903,500$ incident cases globally every year, including 258,400 mortalities (17). Despite the improvement of diagnostic technology and effective development of screening processes, the morbidity of prostate cancer in Asian and European countries including China in recent years has increased (18). However, during the progression of treatment, it is inevitable for patients with prostate cancer to develop resistance to hormone therapy within several years, namely castrate-resistant prostate cancer (17). For hormone-independent prostate cancer, which is insensitive to endocrinotherapy, there is no consistent ideal therapeutic method; therefore, it has become an increasingly difficult issue (4). The activation of caspases associated with endoplasmic reticulum stress occurs during the early phase of apoptosis, when cells suffer from a stress reaction, resulting in increases in mitochondrial outer membrane permeability (19). Cytochrome $c$ is released into the cytoplasm, which then promotes the formation of the apoptosis complex, activates effector caspases and causes apoptosis (8). The present study indicated that thapsigargin significantly decreased cell proliferation, and increased the apoptosis rate and caspase-9/3 activities in PC3 cells. 
The mTOR signal transduction pathway primarily participates in the synthesis of proteins (20). A previous study concerning the suspected associations between single nucleotide polymorphisms in the signal transduction pathway gene and prostate cancer conducted worldwide (21). The mTOR signaling pathway is an important therapeutic target of prostate cancer (21). mTOR is a highly conserved serine/threonine kinase, belonging to the phosphoinositide 3-kinase (PI3K) family, and is also the downstream effector of the PI3K/Akt signaling pathway (21). mTOR is widely expressed in cells and regulates multiple cellular functions in different cells, including survival and proliferation (21). On the one hand, the mammalian target of rapamycin complex 1 regulates translation, including 5 'terminal oligopyrimidine tract mRNAs (20). Conversely, mTORC1 serves as the central pivot of the cascade signal channel that regulates RNA translation. The present study identified that thapsigargin inhibits p-Akt and p-mTOR protein expression in prostate cancer cells. Chiu et al (22) demonstrated that thapsigargin induces pro-death autophagy through Akt-mTOR-Ribosomal protein S6 kinase $\beta$-1 pathway inhibition in multidrug-resistant lung cancer cells. These data suggest the role of thapsigargin-mediated inhibition of the Akt-mTOR pathway in prostate cancer cells.

The cytoskeleton is a network structure consisting of cellular internal proteins, including canaliculi, microfilaments and intermediate filaments (23). Microfilaments are the smallest of the three skeleton structures, are composed of actin and exist in the form of free and globular actin G-actin or F-actin (23). Previous data indicate that the changes in actin polymerization/depolymerization, namely actin skeleton reconstruction, serve important regulatory roles in phenotypes of malignant cells (24). It has been suggested that intervention in cellular skeleton microfilament actin reconstruction may be a functional target of anticancer drugs, and may be regarded as a basis for developing novel antineoplastic drugs (25). Yip et al (26) suggested that thapsigargin modulates osteoclastogenesis through the regulation of F-actin and reactive oxygen species production (27). The present study indicated that thapsigargin inhibits F-actin expression in prostate cancer cells.

The highly localized activities of cofilin-1 generate schistose pseudopodia and determine cellular motor direction; cofilin-1 serves an important role in cell migration (9). Concomitantly, there have been studies demonstrating that cofilin-1 is an important regulatory factor of cancer cell metastasis and invasion (9). The overexpression of cofilin-1 protein levels increases the migratory rate of cancer cells, but inhibiting its expression may markedly reduce cancer cell growth (9). An overexpression of cofilin-1 at a mRNA level has been revealed in breast cancer cell subsets (11). A previous study identified that cofilin-1 also exhibited overexpression in a number of types of cancer cells (11). The present study suggested that thapsigargin induces cofilin-1 expression in prostate cancer cells. Wang et al (27) demonstrated that thapsigargin induces apoptosis of human lung adenocarcinoma cells through cofilin-1 and paxillin.

Protein-tyrosine kinase 6 (Brk) promotes the migration and infiltration of prostate cancer, and is activated by paxillin phosphorylation (10). Paxillin is the binding protein and acting substrate of Brk (10). Then, the adaptor molecule CrkII isoform activates guanosine triphosphatase Ras-related $\mathrm{C} 3$ botulinum toxin substrate 1 , to cause cell migration and infiltration (10). In addition, paxillin may also combine with multiple oncogenic proteins, disordering or even dysregulating normal adhesion, and control the growth factor signaling passageway required for cell proliferation, so as to participate in tumor metastasis (23). The abnormal expression of paxillin is associated with the occurrence, invasion and metastasis of prostate cancer (23). The present study identified that thapsigargin significantly inhibited paxillin protein expression in prostate cancer PC3 cells. Wang et al (27) revealed that thapsigargin induces apoptosis in human lung adenocarcinoma cells through cofilin-1 and paxillin. These results of the present study suggest that curcumin inhibits the tumor growth of prostate cancer cells by modulating the F-actin/cofilin-1/paxillin pathway.

In summary, the present study suggests that thapsigargin significantly decreased cell proliferation, and increased the apoptosis rate and caspase-9/3 activities in PC3 cells. Additionally, inhibition of Akt-mTOR pathway and modulation of the F-actin/cofilin-1/paxillin pathway by thapsigargin may decreased cell growth in prostate cancer cells. These data suggest that thapsigargin may be a novel drug that suppresses the growth of prostate cancer cells through the Akt-mTOR and F-actin/cofilin-1/paxillin pathways.

\section{Acknowledgements}

Not applicable.

Funding

No funding was received.

\section{Availability of data and materials}

The analyzed data sets generated during the study are available from the corresponding author on reasonable request.

\section{Authors' contributions}

XW designed the experiment. FH and PW performed the experiments. XW and FH analyzed the data. XW wrote the manuscript.

\section{Ethics approval and consent to participate}

Not applicable.

\section{Consent for publication}

Not applicable.

\section{Competing interests}

The authors declare that they have no competing interests.

\section{References}

1. D'Amico AV, Chen MH, Renshaw A, Loffredo M and Kantoff PW: Long-term follow-up of a randomized trial of radiation with or without androgen deprivation therapy for localized prostate cancer. JAMA 314: 1291-1293, 2015. 
2. Fedorov A, Fluckiger J, Ayers GD, Li X, Gupta SN, Tempany C, Mulkern R, Yankeelov TE and Fennessy FM: A comparison of two methods for estimating DCE-MRI parameters via individual and cohort based AIFs in prostate cancer: A step towards practical implementation. Magn Reson Imaging 32: 321-329, 2014.

3. Yu EY, Massard C, Gross ME, Carducci MA, Culine S, Hudes G, Posadas EM, Sternberg CN, Wilding G, Trudel GC, et al: Once-daily dasatinib: Expansion of phase II study evaluating safety and efficacy of dasatinib in patients with metastatic castration-resistant prostate cancer. Urology 77: 1166-1171, 2011.

4. Houédé N, Pulido M, Mourey L, Joly F, Ferrero JM, Bellera C, Priou F, Lalet C, Laroche-Clary A, Raffin MC, et al: A phase II trial evaluating the efficacy and safety of efavirenz in metastatic castration-resistant prostate cancer. Oncologist 19: 1227-1228, 2014.

5. Thomas R, Williams M, Sharma H, Chaudry A and Bellamy P: A double-blind, placebo-controlled randomised trial evaluating the effect of a polyphenol-rich whole food supplement on PSA progression in men with prostate cancer-the U.K. NCRN Pomi-T study. Prostate Cancer Prostatic Dis 17: 180-186, 2014.

6. Obakan P, Arisan ED, Coker-Gurkan A and Palavan-Unsal N: Epibrassinolide-induced apoptosis regardless of p53 expression via activating polyamine catabolic machinery, a common target for androgen sensitive and insensitive prostate cancer cells. Prostate 74: 1622-1633, 2014.

7. Reshma RS, Sreelatha KH, Somasundaram V, Satheesh Kumar S, Nadhan R, Nair RS and Srinivas P: Plumbagin, a naphthaquinone derivative induces apoptosis in BRCA $1 / 2$ defective castrate resistant prostate cancer cells as well as prostate cancer stem-like cells. Pharmacol Res 105: 134-145, 2016.

8. Kwegyir-Afful AK, Ramalingam S, Purushottamachar P, Ramamurthy VP and Njar VC: Galeterone and VNPT55 induce proteasomal degradation of AR/AR-V7, induce significant apoptosis via cytochrome $\mathrm{c}$ release and suppress growth of castration resistant prostate cancer xenografts in vivo. Oncotarget 6: 27440-27460, 2015.

9. Zhu B, Fukada K, Zhu H and Kyprianou N: Prohibitin and cofilin are intracellular effectors of transforming growth factor beta signaling in human prostate cancer cells. Cancer Res 66: 8640-8647, 2006.

10. Lu LI, Fu NI, Luo XU, Li XY and Li XP: Overexpression of cofilin 1 in prostate cancer and the corresponding clinical implications. Oncol Lett 9: 2757-2761, 2015.

11. Sundram V, Chauhan SC, Ebeling M and Jaggi M: Curcumin attenuates $\beta$-catenin signaling in prostate cancer cells through activation of protein kinase D1. PLoS One 7: e35368, 2012.

12. Hammes SR, Miedlich SU and Sen A: Paxillin and steroid signaling: From frog to human. Methods Mol Biol 1204: 95-108, 2014.

13. Bokobza SM, Ye L, Kynaston HG and Jiang WG: Growth and differentiation factor-9 promotes adhesive and motile capacity of prostate cancer cells by up-regulating FAK and Paxillin via Smad dependent pathway. Oncol Rep 24: 1653-1659, 2010.

14. Janyou A, Changtam C, Suksamrarn A, Tocharus C and Tocharus J: Suppression effects of O-demethyldemethoxycurcumin on thapsigargin triggered on endoplasmic reticulum stress in SK-N-SH cells. Neurotoxicology 50: 92-100, 2015.

15. Drexler HC: Synergistic apoptosis induction in leukemic cells by the phosphatase inhibitor salubrinal and proteasome inhibitors. PLoS One 4: e4161, 2009.
16. Muramatsu Y, Maemoto T, Iwashita A and Matsuoka N: Novel neuroprotective compound $\mathrm{SCH}-20148$ rescues thymocytes and $\mathrm{SH}-\mathrm{SY} 5 \mathrm{Y}$ cells from thapsigargin-induced mitochondrial membrane potential reduction and cell death. Eur J Pharmacol 563: 40-48, 2007.

17. Wolpin BM, O'Reilly EM, Ko YJ, Blaszkowsky LS, Rarick M, Rocha-Lima CM, Ritch P, Chan E, Spratlin J, Macarulla T, et al: Global, multicenter, randomized, phase II trial of gemcitabine and gemcitabine plus AGS-1C4D4 in patients with previously untreated, metastatic pancreatic cancer. Ann Oncol 24: 1792-1801, 2013.

18. Matsumoto K, Hagiwara M, Tanaka N, Hayakawa N, Ishida M, Ninomiya A, Nakajima Y and Nakamura S: Survival following primary androgen deprivation therapy for localized intermediate- or high-risk prostate cancer: Comparison with the life expectancy of the age-matched normal population. Med Oncol 31: 979, 2014.

19. Cella D, Ivanescu C, Holmstrom S, Bui CN, Spalding J and Fizazi K: Impact of enzalutamide on quality of life in men with metastatic castration-resistant prostate cancer after chemotherapy: Additional analyses from the AFFIRM randomized clinical trial. Ann Oncol 26: 179-185, 2015.

20. Kato M, Banuelos CA, Imamura Y, Leung JK, Caley DP, Wang J, Mawji NR and Sadar MD: Cotargeting androgen receptor splice variants and mTOR signaling pathway for the treatment of castration-resistant prostate cancer. Clin Cancer Res 22: 2744-2754, 2016.

21. Fang F, Wang L, Zhang S, Fang Q, Hao F, Sun Y, Zhao L, Chen S, Liao H and Wang L: CD147 modulates autophagy through the $\mathrm{PI} 3 \mathrm{~K} / \mathrm{Akt} / \mathrm{mTOR}$ pathway in human prostate cancer PC-3 cells. Oncol Lett 9: 1439-1443, 2015.

22. Chiu LY, Hu ME, Yang TY, Hsin IL, Ko JL, Tsai KJ and Sheu GT: Immunomodulatory protein from ganoderma microsporum induces pro-death autophagy through Akt-mTOR-p70S6K pathway inhibition in multidrug resistant lung cancer cells. PLoS One 10: e0125774, 2015.

23. Asahara S, Shibutani Y, Teruyama K, Inoue HY, Kawada Y, Etoh H, Matsuda T, Kimura-Koyanagi M, Hashimoto N, Sakahara M, et al: Ras-related C3 botulinum toxin substrate 1 (RAC1) regulates glucose-stimulated insulin secretion via modulation of F-actin. Diabetologia 56: 1088-1097, 2013.

24. Yu Y, Yang O, Fazli L, Rennie PS, Gleave ME and Dong X: Progesterone receptor expression during prostate cancer progression suggests a role of this receptor in stromal cell differentiation. Prostate 75: 1043-1050, 2015

25. Luo Y, Cui X, Zhao J, Han Y, Li M, Lin Y, Jiang Y and Lan L: Cells susceptible to epithelial-mesenchymal transition are enriched in stem-like side population cells from prostate cancer. Oncol Rep 31: 874-884, 2014

26. Yip KH, Zheng MH, Steer JH, Giardina TM, Han R, Lo SZ, Bakker AJ, Cassady AI, Joyce DA and Xu J: Thapsigargin modulates osteoclastogenesis through the regulation of RANKL-induced signaling pathways and reactive oxygen species production. J Bone Miner Res 20: 1462-1471, 2005.

27. Wang F, Liu DZ, Xu H, Li Y, Wang W, Liu BL and Zhang LY: Thapsigargin induces apoptosis by impairing cytoskeleton dynamics in human lung adenocarcinoma cells. ScientificWorldJournal 2014: 619050, 2014. 